\title{
Eksekusi Hak Tanggungan Terhadap Kredit Macet Bank
}

\author{
Yustiana Yustiana \\ Sekolah Tinggi Ilmu Hukum Lamaddukelleng, Sengkang \\ ${ }^{\Omega}$ Surel Koresponden: yustianayuyun@gmail.com
}

\begin{abstract}
:
This study aims to determine the execution of mortgage rights if a bad credit occurs at Sengkang BRI Bank and also to determine the factors that influence if the execution of a non-performing loan mortgage is not implemented. Data collection methods used were interviews and literature study, then the data were analyzed descriptively. The results showed that the execution of mortgage rights in the case of bad credit at Bank BRI Sengkang was not yet effective. This is due to frequent negligence on the part of the Bank concerned in the procedure for credit disbursement, especially in credit agreements involving third parties. The factors that influence the execution of the mortgage are creditor and debtor factors. As long as there is an agreement between the two parties, there is a possibility that there will be no execution of the mortgage rights and if the execution is there the implementation will be carried out by peaceful execution. Keywords: execution; mortgage right; bad debts;
\end{abstract}

\begin{abstract}
Abstrak:
Penelitian ini bertujuan untuk mengetahui eksekusi terhadap hak tanggungan bila terjadi terjadi kredit macet di Bank BRI Sengkang dan juga untuk mengetahui faktor-faktor yang mempengaruhi bila tidak dilaksanakannya eksekusi hak tanggungan kredit macet. Metode pengumpulan data yang digunakan adalah wawancara dan studi kepustakaan, kemudian data dianalisis secara deskriptif. Hasil penelitian menunjukkan bahwa eksekusi terhadap hak tanggungan bagi kasus kredit macet di Bank BRI Sengkang sebagian belum efektif. Hal ini disebabkan sering adanya kelalaian dipihak Bank yang bersangkutan dalam prosedur pencairan kredit, utamanya pada perjanjian kredit yang melibatkan pihak ketiga. Adapun faktor yang berpengaruh terhadap pelaksanaan eksekusi pada hak tanggungan adalah faktor kreditor dan debitor. Sepanjang ada kesepakatan antara kedua belah pihak, maka kemungkinan tidak akan terjadi eksekusi hak tanggungan dan kalaupun eksekusi itu ada maka pelaksanaannya akan ditempuh dengan cara eksekusi damai.

Kata Kunci: eksekusi; hak tanggungan; kredit macet;
\end{abstract}

Submit : 21-03-2020

Accepted: 14-04-2020

Doi: https://doi.org/10.56087/aijih.v23i1.38

\section{PENDAHULUAN}

Meningkatnya angka pertumbuhan ekonomi tidak terlepas dari upaya pemerintah untuk meningkatkan dan mengembangkan dunia usaha kecil dan menengah ditanah air. Pelaku ekonomi disektor riil adalah pemerintah maupun masyarakat sebagai 
perseorangan ataupun sebagai badan usaha. Untuk mengembangkan dunia usaha agar pertumbuhan ekonomi dapat dipertahankan, maka diperlukan dana yang cukup besar untuk memenuhi kebutuhan berupa fasilitas perkreditan, baik dari Bank Pemerintah maupun pada Bank Swasta. Pengambilan kredit mempunyai syaratsyarat tertentu yang dapat digunakan sebagai modal usaha. Salah satu persyaratan untuk mengambil kredit di Bank adalah adanya hak tanggungan yang pada umumnya berbentuk sertifikat tanah dan atau bangunannya. ${ }^{1}$

Dewasa ini perbankan telah mengalami perkembangan yang cukup menggembirakan dalam menyalurkan kredit kepada masyarakat. Pemberian kredit oleh Bank kepada debitor dilakukan sebagai salah satu usaha bank untuk memperoleh keuntungan. Namun dalam memberikan kredit bank kepada nasabah, bank bertindak hati-hati dan berkeyakinan bahwa debitor akan mampu untuk melunasi utangnya sesuai dengan perjanjian. Untuk memperoleh keyakinan, sebelum memberikan kredit bank harus melakukan penilaian yang seksama terhadap watak, kemampuan, modal, agunan dan prospek usaha debitor. ${ }^{2}$

Agar kredit yang diberikan bank kepada debitor menjadi aman dalam pengembaliannya dan tidak menjadi kredit bermasalah, maka bank meminta kepada debitor untuk memberikan suatu jaminan bagi pelunasan utang debitor. Adannya jaminan pengambilan kredit ini merupakan implementasi dan penjelasan Pasal 8 Undang-Undang No.10 Tahun 1998 Tentang Perubahan atas Undang-Undang Nomor 7 Tahun 1992 mengenai Perbankan yang menyatakan bahwa "kredit yang diberikan oleh bank mengandung resiko sehingga dalam pelaksanaannya bank harus memperhatikan asas-asas perkreditan".

Pada dasarnya jenis-jenis jaminan kredit di Indonesia terdiri dari: ${ }^{3}$ (1) jaminan perorangan dan (2) jaminan kebendaan. Dalam praktek perkreditan di bank, salah satu jaminan yang diminati oleh bank sebagai jaminan kredit adalah hak tanggungan. Keberadaan hak tanggungan ini sebagaimana diatur dalam Undang-Undang No.4 Tahun 1996 tentang Hak Tanggungan ini mempunyai ciri-ciri yang memberikan

\footnotetext{
1 Satrio, J. (1998). Hukum jaminan, hak jaminan kebendaan, hak tanggungan. Citra Aditya Bakti.

2 Untung, H. B. (2000). Kredit perbankan di Indonesia. Andi. hal 19

${ }^{3}$ Rahman, H. (1998). Aspek-Aspek Hukum Pemberian Kredit Perbankan di Indonesia, citra Aditya Bakti. hal, 44
} 
perlindungan hukum bagi kreditor (bank). Oleh karena itu bank sebagai kreditor dalam memberikan kredit kepada debitor yang dijamin dengan hak tanggungan akan aman dalam pengembalian kredit tersebut.

Memori penjelasan Undang-undang No.4 Tahun 1996 memberikan ciri-ciri hak tanggungan sebagai berikut :4

(1) Memberikan hak preferensi kepada pemegangnya

(2) Mengikuti obyek yang dijamin, dalam tangan siapapun obyek itu berada

(3) Memenuhi asas spesialitas sehingga mengikat pihak ketiga dan memberikan kepastian hukum

(4) Mudah dan pasti pelaksanaan eksekusinya

Untuk kredit yang dijamin dengan hak tanggungan apabila dalam perjalannya ternyata debitor wanprestasi/cedera janji yaitu debitor tidak dapat membayar lunas utang-utangnya kepada bank yang bersangkutan dan pada akhirnya menjadi kredit macet, 5 maka upaya yang paling cepat bagi pihak bank selaku kreditor untuk menyelesaikan kredit macet itu adalah dengan melakukan penjualan obyek hak tanggungan di Pengadilan Negeri setempat.

Namun dalam prakteknya, khususnya kasus-kasus tertentu masih ada kendalakendala yang menghambat pelaksanaan eksekusi hak tanggungan, misalnya debitor yang pertama hampir selesai angsuran kredit dan bermohon untuk penambahan kredit dengan jumlah yang besar dengan mengikut sertakan sertifikat hak tanggungan pihak ketiga. Dengan dasar kepercayaan pihak bank mengeluarkan kredit yang diminta tanpa adanya perjanjian antara debitor pertama dan kedua bersama bank yang bersangkutan. Setelah terjadi kredit macet pihak bank tidak dapat mengeksekusi hak tanggungan debitor kedua sehingga pihak bank dirugikan. ${ }^{6}$

Berdasarkan uraian diatas, maka penulis tertarik untuk menkaji lebih jauh serta menganalisis pelaksanaan eksekusi hak tanggungan sebagai judul penulisanm sehingga yang menjadi permasalahan pada artikel ini: seperti apakah pelaksanaan eksekusi terhadap hak tanggungan bila terjadi sebuah keadaan kredit macet di bank

\footnotetext{
${ }^{4}$ Munir Fuady, (2006), Hukum Perkreditan Kontemporer, Bandung, Citra Aditya Bakti, hal 66

5 Syarif, F. (2019). Perkembangan Hukum Ekonomi Syariah di Indonesia. Pleno Jure, 9(2), 1-16.

${ }^{6}$ Hadimulyo, M. A. (1997). Kajian Alternatif Penyelesaian Sengketa di Luar Pengadilan. ELSAM, Yakarta. hal 101
} 
BRI Cabang Sengkang, dan faktor apa sajakah yang berpengaruh terhadap tidak dilaksanakannya sebuah tindakan eksekusi hak tanggungan terhadap kredit macet.

\section{METODE}

Penelitian ini dilakukan dalam wilayah hukum Kabupaten Wajo dengan obyek penelitian yakni Bank Rakyat Indonesia, dengan pertimbangan bahwa pada bank tersebut terdapat masalah kredit macet yang dapat diselesaikan baik melalui lembaga peradilan maupun secara internal di bank yang bersangkutan. Populasi dalam penelitian ini adalah Bank BRI dan Hakim Pengadilan Negeri Sengkang yang mengetahui tentang eksekusi hak tanggungan dan nasabah yang pernah mengalami kredit macet. Sampel penelitian ini ditetapkan dengan cara purposive sampling sebanyak 10 orang yang terdiri dari :
a. Karyawan bank BRI sebanyak 3 (satu) orang
b. Hakim Pengadilan Negeri Sengkang sebanyak 3 (satu) orang
c. Nasabah yang bermasalah 4 (tiga) orang

Dalam penelitian ini data yang hendak dikumpulkan untuk dianalisis adalah data Primer, yakni yang diperoleh secara langsung dari responden melalui wawancara (interview) maupun dari hasil kuisioner yang telah diedarkan kepada responden. Data Sekunder, yakni data yang diperoleh dari dokumen-dokumen, jurnal ilmiah, literatur-literatur maupun dari ketentuan perundang-undangan yang sangat berkaitan dengan pembahasan penelitian ini. Teknik pengumpulan data yaitu dengan melakukan observasi yaitu melakukan pengamatan langsung ke Kantor Pengadilan Negeri Sengkang dan BRI Sengkang untuk melihat dan mendapatkan informasi mengenai kasus kredit macet. Wawancara mendalam (in depth interview) yaitu mengumpulkan data melalui wawancara langsung dengan informan yang diwawancarai berkaitan dengan kasus macet yaitu nasabah yang bermasalah. Dokumentasi juga digunakna dalam penelitian ini untuk mencari informasi berdasarkan kejadian perkara secara administratif dan alasan-alasan terjadinya perkara yang tercatat dan terlaporkan di Pengadilan Negeri Sengkang. Digunakan analisis kualitatif yang dimaksudkan untuk menganalisis data yang tidak dapat dikualifikasikan, seperti bahasa pustaka, hasil wawancara, peraturan perundang- 
undangan yang berhubungan dengan masalah yang dikaji, dan analisis kuantitatif digunakan dalam menyajikan data bahasa simbol berupa tabel.

\section{PEMBAHASAN}

A. Pelaksanaan Eksekusi Objek Agunan Hak Tanggungan sebagai Jaminan Kredit

Undang-undang telah menyediakan lembaga parate eksekusi Hak Tanggungan sebagaimana yang dimaksud dalam Pasal 6 Undang-undang Hak Tanggungan sebagai jalan keluar (way out) apabila debitur cidera janji atau wanprestasi dalam memenuhi kewajiban pembayarannya kepada bank selaku kreditur. ${ }^{7}$ Akan tetapi dalam praktiknya dilapangan masih terdapat beberapa kendala yang dialami oleh bank dalam pelaksanaan parate eksekusi Hak Tanggungan tersebut.

Kendala ini baik yang berupa kendala yang dihadapi pada awal pelaksanaan parate eksekusi hak tanggungan, maupun kendala lain yang dihadapi oleh bank setelah pelaksanaan eksekusi Hak Tanggungan tersebut

Tabel 1.

Pelaksanaan parate eksekusi pada BRI Cabang Kabupaten Wajo tahun 2018-2019

\begin{tabular}{cccc}
\hline \hline Tahun & $\begin{array}{c}\text { Pelaksanaan } \\
\text { Parate Eksekusi }\end{array}$ & Berhasil & Gagal \\
\hline \hline 2018 & 3 & 5 & 2 \\
2019 & 6 & 7 & 3 \\
Total & 9 & 12 & 5 \\
\hline \hline
\end{tabular}

Data Pembiayaan Bermasalah BRi di Seluruh Cabang Kab Wajo 2018- 2019

Data nasabah yang telah terdaftar sebagai nasabah KNLW (Kewajiban Nasabah Lewat Waktu) dimana nasabah tersebut tercatat sebagai nasabah yang berkolektibiltas 3, 4 dan 5. Tahun 2019 pelaksanaan parate eksekusi dilakukan terhadap 9 (Sembilan) aset nasabah, dengan hasil 5 (lima) aset nasabah yang berhasil dan 6 (enam) gagal dilakukan parate eksekusi. Pada 2019, dengan jumlah 16 (emam belas) aset nasabah, yang berhasil hanya 7 (tujuh). Adapun beberapa

7 Pratama, B. A. (2010). Analisis faktor-faktor yang mempengaruhi kebijakan penyaluran kredit perbankan (Studi pada Bank Umum di Indonesia Periode Tahun 2005-2009) (Doctoral dissertation, Universitas Diponegoro). 
kendala yang dihadapi oleh bank BRI Cabang di kabupaten Wajo dalam pelaksanaan parate eksekusi adalah :

1. Terdapat Perlawanan Debitur

Pada periode tahun 2018-2019 terdapat 9 (sembilan) gugatan yang diajukan kepada bank di kabupaten Wajo. Diantara sejumlah gugatan tersebut, beberapa diantaranya dilakukan oleh debitur sebelum pelaksanaan eksekusi hak tanggungan dilakukan. Materi gugatan yang diajukan oleh debitur atau pihak ketiga biasanya mengenai jumlah hutang yang dianggap tidak jelas/tidak pasti, adanya kesalahan dalam Pengikatan Jaminan atau Perjanjian pembiayaan, objek tanah dan bangunan dimiliki oleh pihak ketiga, hingga materi mengenai harta bersama atau harta warisan.

Atas adanya gugatan tersebut, pihak KPKNL biasanya akan melakukan penundaan atau bahkan menolak permohonan lelang eksekusi yang diajukan oleh bank apabila terdapat gugatan dari debitur atau pihak ketiga yang masih belum diselesaikan sehubungan dengan tanah dan atau bangunan yang akan menjadi objek lelang eksekusi Hak Tanggungan. Sikap konservatif KPKNL seperti ini didasarkan pada pengalaman dilapangan yang mereka alami dimana seringkali Pejabat Lelang KPKNL yang melaksanakan lelang eksekusi atas tanah dan bangunan yang dimohonkan oleh bank, dijadikan sebagai salah satu pihak Tergugat dalam gugatan yang dilakukan oleh debitur, dan atau akan direpotkan oleh pemanggilan dari Pihak Kepolisian atau Penyidik mana kala debitur membawa permasalahan tersebut ke ruang lingkup pidana melalui suatu laporan polisi.

Mengatasi gugatan tersebut bank yang berada di kabupaten Wajo menjawab gugatan tersebut dengan melakukan perlawanan dengan mengikuti proses beracara dalam peradilan perdata pada umumnya. Dimana akhirnya gugatan yang diajukan debitur kepada bank berakhir pada proses duplik maupun jawaban gugatan. ${ }^{8} \mathrm{Hal}$ ini dikarenakan debitur maupun kuasa hukumnya kurang cermat dalam melihat ataupun membaca

8 Emerson, J, (2001), Alternatif PenyelesaianSengketa Di Luar Pengadilan, Jakarta, Gramedia Pustaka Utama, hal 120 
akad pembiayaan yang telah disepakati oleh pihak debitur dengan bank. ${ }^{9}$ Sebagaimana dalam akad pembiayaan tersebut disebutkan dan dibacakan oleh Notaris pada saat melakukan pengikatan pembiayaan, bahwa pada Pasal penyelesaian sengketa terdapat klausul "Apabila terjadi sengketa atau konflik antara Bank dengan Nasabah maka diselesaikan secara musyawarah dan apabila tidak ditemukan kata mufakat maka dapat diselesaikan melalui Badan Arbitrase Nasional yang putusannya bersifat final dan binding". ${ }^{10}$ Akan tetapi, pihak debitur mengajukan gugatan melalui Pengadilan Negeri sehingga secara aturan hukum Hakim dapat membatalkan gugatan tersebut berkenaan dengan kompetensi absolut pelaksanaan gugatan.

2. Kesulitan Mendapat Pembeli Lelang pada Priode Tahun 2018-2019 Terdapat 5 (lima) aset yang yang gagal dilakukan parate eksekusi disebabkan oleh sulitnya mencari pembeli lelang atas tanah danbangunan yang menjadi obyek lelang eksekusi tersebut. ${ }^{11}$ Tidak semua masyarakat mengerti dan mengetahui mekanisme pelaksanaan lelang eksekusi hak tanggungan pada Bank BRI Cabang Sengkang, Wajo. Adanya kekhawatiran masyarakat terhadap kemungkinan terjadi permasalahan kepemilikan atas tanah dan bangunan yang dibeli melalui lelang tersebut, misalnya adanya gugatan dari debitur atau pemilik lama tanah dan bangunan tersebut yang tidak dapat menerima dilakukannya lelang eksekusi atas tanah dan bangunan miliknya.

Kekhawatiran masyarakat juga timbul saat obyek tanah dan bangunan yang dilelang tersebut secara fisik masih berada dalam penguasaan debitur atau pihak ketiga lainnya. Meskipun pembeli lelang dapat mengajukan pengosongan tanah dan bangunan tersebut berdasarkan ketentuan Pasal 200 ayat 11 HIR, namun pihak Pengadilan Negeri umumnya tidak dapat

\footnotetext{
${ }^{9}$ Emerson, J. (2001). Alternatif Penyelesaian Sengketa di luar Pengadilan (negosiasi, mediasi, konsiliasi dan arbitrasi). Jakarta: Gramedia Pustaka.

10 Wijoyo Suprapto, 2007, Mekainisme Alternatif Penyelesaian Sengketa, Jakarta, Anaska hal, 91

11 Wawancara Akbar Amda 12 Agustus 2019
} 
menerima Permohonan Pengosongan atas tanah dan bangunan yang dibeli melalui lelang parate eksekusi hak tanggungan. ${ }^{12}$

Pihak pengadilan Negeri Sengkang hanya menerima permohonan pengosongan atas tanah dan bangunan yang dibeli oleh Pihak Pembeli melalui lelang eksekusi yang dilaksanakan fiat pengadilan (melalui Pengadilan Negeri). ${ }^{13}$ Beberapa pengadilan negeri bahkan berpendapat bahwa pengosongan tanah dan bangunan yang diperoleh dari lelang eksekusi hak tanggungan harus dilakukan melalui mekanisme gugatan terlebih dahulu oleh pemohon/pemenang lelang. Kalaupun permohonan pengosongan berdasarkan Pasal 200 ayat 11 HIR tersebut diterima oleh Pengadilan Negeri Sengkang, pemenang lelang akan menanggung seluruh biaya yang ditimbulkan sehubungan dengan proses pengosongan tersebut. Semakin sulit kondisi lapangan untuk melakukan proses pengosongan, maka semakin besar pula biaya pengosongan yang harus dikeluarkan oleh pemenang lelang.

Hal ini menjadi suatu pertimbangan khusus bagi masyarakat untuk berfikir berulang kali ketika hendak membeli tanah dan atau bangunan melalui lelang eksekusi Hak Tanggungan. Terhadap aset yang sulit untuk dijual tersebut, Bank melakukan pendekatan persuasif kembali kepada debitur agar debitur dapat memberikan kuasa jual dan pengakuan utang secara notariel. ${ }^{14}$

Hal ini akan memudahkan bank untuk dapat melakukan penjualan aset secara bawah tangan. Selain itu bank juga melakukan hapus buku (write off) terhadap utang debitur sehingga dalam catatan bank utang tersebut telah lunas namun tidak hapus tagih. Tindakan ini wajib mendapatkan persetujuan dari dewan direksi bank. ${ }^{15}$ Persyaratan lelang yang harus disiapkan oleh Bank di BRI Cabang Kabupaten Wajo dan kemudian

\footnotetext{
Cipta.

13 Wawancara Hakin Pengadilan Negeri Sengkang, Suardi 18 Agusuts 2019.

${ }^{14}$ Suyatno, T. (1988). Kelembagaan perbankan. Gramedia Pustaka Utama. hal 58

15 Sutan Remy Sjahdeini, S. H. (2018). Perbankan Syariah: Produk-produk dan aspek-aspek hukumnya. Kencana. hal 83
}

12 Situmorang, V. M., \& Sitanggang, C. (1993). Grosse Akta dalam pembuktian dan Eksekusi. Rineka 
diserahkan kepada Balai Lelang/KPKNL sebagai lampiran dari surat permohonan Lelang adalah sebagai berikut:

1) Copy Perjanjian Kredit

2) Copy Sertifikat Hak Tanggungan

3) Copy bukti kepemilikan hak atas tanah

4) Copy perincian hutang atau jumlah kewajiban debitur yang harus dipenuhi

5) Copy surat somasi dari pihak bank kepada debitur

6) Surat asli pernyataan dari Bank yang menyatakan akan bertanggung jawab apabila terjadi gugatan perdata atau tuntutan pidana

7) Laporan asli dari penilaian tanah dan atau bangunan yang dikeluarkan oleh perusahaan penilaian.

Setelah dokumen persyaratan lelang dinyatakan lengkap, maka Kantor Balai Lelang/KPKNL yang ditunjuk oleh bank akan mengeluarkan penetapan jadwal lelang secara tertulis kepada bank selaku pemohon lelang. Surat penetapan tersebut berisi sebagai berikut:

a. Penetapan tempat dan waktu pelaksanaan lelang

b. Permintaan untuk melaksanakan pengumuman lelang sesuai ketentuan dan menyampaikan bukti pengumumannya.

c. Hal-hal yang perlu disampaikan kepada penjual, misalnya mengenai harga limit. Penguasaan secara fisik terhadap barang bergerak yang dilelang, dan lain sebagainya.

Berdasarkan penetapan jadwal lelang yang telah dikeluarkan oleh Balai Lelang/KPKNL tersebut, Balai Lelang/KPKNL yang ditunjuk oleh bank akan membantu mengumumkan jadwal pelaksanaan lelang yaitu pengumuman pertama yang dapat dilakukan pada selebaran atau pengumuman di tempat Balai Lelang/KPKNL, dan pengumuman kedua pada surat kabar harian yang terbit di kota atau kabupaten tempat jaminan berada. Pengumuman lelang tersebut antara lain berisikan informasi sebagai berikut :

1) Identitas penjual

2) Hari, tanggal, waktu dan tempat pelaksanaan lelang dilakukan 
3) Lokasi, luas tanah, jenis hak atas tanah, dan ada atau tidak adanya bangunan yang berdiri diatasnya

4) Uang jaminan penawaran lelang meliputi besaran, jangka waktu, cara dan tempat penyetoran, dalam hal dipersyaratkan adanya uang jaminan penawaran lelang

5) Nilai limit lelang

6) Mekanisme penawaran lelang

7) Jangka waktu kewajiban pembayaran lelang oleh pembeli

Selanjutnya berdasarkan ketentuan pasal 22 ayat (1) dan (2) peraturan menteri keuangan No.93/PMK.06/2010 tentang petunjuk pelaksanaan lelang, pelaksanaan lelang atas tanah atau bangunan wajib dilengkapi dengan Surat Keterangan Tanah (SKT) dari kantor pertanahan setempat. Permintaan penerbitan SKT kepada kepala kantor pertanahan setempat diajukan oleh Balai Lelang Swasta yang biaya pengurusannya menjadi tanggung jawab bank selaku permohonan lelang.

Setelah melakukan pengumuman lelang, maka bank akan membuat surat pemberitahuan kepada debitur tentang jadwal pelaksanaan lelang yang akan dilakukan. Pemberitahuan pelelangan juga dilakukan terhadap penghuni bangunan dan pemilik barang (dalam hal tanah dan atau bangunan dikuasai oleh pihak ketiga). Apabila hal tersebut di atas telah dilakukan oleh penjual maka lelang dapat dilakukan sesuai dengan jadwal yang ditentukan. Pada hari yang telah ditetapkan sesuai dengan jadwal penetapan lelang, pelaksanaan lelang eksekusi dilakukan Balai Lelang/ KPKNL. Penawaran lelang akan dilakukan dimulai dari harga limit lelang yang ditetapkan. Atas penawaran tertinggi dari peserta lelang, maka pejabat lelang akan menunjuk dan menetapkan penawaran tertinggi tersebut sebagai pemegang lelang secara sah. Paling lambat tiga hari setelah tanggal pelaksanaan lelang dilakukan, pemegang lelang harus menyetorkan dana pelunasan sesuai dengan harga yang terbentuk dilelang setelah dikurangi dengan nilai jaminan lelang yang telah ia setorkan sebelumnya. 
B. Faktor yang Mempengaruhi Pelaksanaan Eksekusi Objek Agunan Hak Tanggungan sebagai Jaminan Kredit

Peraturan hukum mengenai Hak Tanggungan adalah suatu perangkat hukum yang digunakan ketika terjadinya perikatan (kesepakatan) pinjam meminjam uang antara Peminjam (Debitur) dengan Pemberi Pinjaman (Bank). Didalam prakteknya calon debitur mengajukan permohonan pinjaman kepada bank dengan menyertakan segala bentuk surat-surat, yaitu identitas peminjam, jaminan pinjaman berupa Akta Kepemilikan atas Tanah dan Bangunan serta surat-surat perizinan usaha jika Debiturnya adalah badan hukum. ${ }^{16}$

Jika menurut Bank permohonan yang diajukan oleh Debitur memenuhi kriteria, maka terjadilah kesepakatan pemberian Fasilitas Kredit atau Pembiayaan kepada Debitur. Tindak lanjut dari kesepakatan pinjam meminjam tersebut, bank memberikan sejumlah dana sebagai bentuk pinjaman kepada Debitur, kemudian Debitur memberikan surat-surat kepemilikan tanah/bangunan ataupun benda lainnya sebagai jaminan pelunasan pinjaman. ${ }^{17}$ Jaminan berupa tanah dan bangunan biasanya dibebani dengan pemasangan Sertifikat Hak tanggungan yang diterbitkan oleh Badan Pertanahan Nasional (BPN).

Kesepakatan fasilitas kredit tersebut, bank memberikan syarat kewajiban agar Debitur membayar pinjaman/kredit dengan sistem angsuran/cicilan setiap bulan dengan tenggang waktu pelunasan antara 1 (satu) s/d 20 (dua puluh) tahun. Apabila Debitur melakukan pembayaran angsurannya secara tepat waktu sampai dengan adanya pelunasan, maka Bank tentu akan memberikan penilaian bahwa Debitur tersebut adalah debitur/nasabah dengan predikat baik, sehingga kemudian Bank akan lebih percaya untuk kembali memberikan pinjaman kepada Debitur dengan predikat baik tersebut, dari semua transaksi pinjam meminjam/kredit tersebut, tentunya ada juga Debitur yang tidak melakukan pembayaran angsuran dengan tepat waktu atau lazimnya disebut Kredit Macet. ${ }^{18}$

16 Sutarno. (2004). Aspek-aspek hukum perkreditan pada bank. Alfabeta.hal 67

17 Retno, R. D. H. (2013). Pelaksanaan Pembiayaan Murabahah Emas Di Bank Danamon Syariah Sidoarjo (Doctoral dissertation, Faculty of Law).

18 Zainul Arifin, M. B. A. (2012). Dasar-dasar manajemen bank syariah. Pustaka Alvabet. 
Bank tentu akan berusaha melakukan penagihan kepada Debitur dengan alasan menghindari resiko kredit macet. Upaya Bank dalam menghindari adanya kredit macet adalah dengan menggunakan aturan kesepakatan atas Jaminan Hak Tanggungan pada sertifikat kepemilikan nasabah jika bentuknya asset tak bergerak (tanah dan bangunan) atau penerapan Jaminan Fidusia jika jaminan berupa benda bergerak (mobil, mesin dan lain-lain). ${ }^{19}$ Terhadap ketentuan pembebanan Hak Tanggungan atas jaminan pinjaman, negara telah menerbitkanperaturan hukum pada Undang-Undang Nomor 4 Tahun 1996 tentang Hak Tanggungan Atas Tanah Beserta Benda-Benda Yang Berkaitan Dengan Tanah. Undang-undang tersebut mengatur tentang Jaminan antara Bank dengan Debitur dalam transaksi pinjam meminjam serta peraturan-peraturan tentang tata cara apabila terjadinya keadaan wanprestasi (tidak membayar) apabila Debitur tidak melaksanakan kewajibannya. ${ }^{20}$

Praktiknya apabila terdapat Debitur yang wanprestasi, biasanya Bank akan mengirimkan Surat Peringatan kepada Debitur agar melaksanakan kewajibannya dalam pembayaran angsuran sesuai dengan yang diperjanjikan. Peringatan tersebut biasanya diajukan paling sedikit sebanyak 3 (tiga) kali untuk memenuhi syarat keadaan wanprestasinya debitur. ${ }^{21}$ Apabila telah diperingati secara patut tetapi Debitur tidak juga melakukan pembayaran kewajibannya, maka Bank melalui ketentuan hukum yang terdapat pada Pasal 6 dan Pasal 20 UndangUndang Nomor 4 tahun 1996 tentang Hak Tanggungan, akan melakukan proses Lelang terhadap Jaminan Debitur. Bank biasanya lebih banyak mengajukan permohonan Lelang Jaminan Hak Tanggungan kepada Balai Lelang Swasta.

Selanjutnya Balai Lelang Swasta akan meneruskan permohonan tersebut kepada KPKNL (Kantor Pelayanan Kekayaan Negara dan Lelang) yang merupakan salah satu unit kerja pada Dit. Jend Kekayaan Negara Departemen Keuangan RI. Ketika Balai Lelang/ KPKNL bertindak sebagai Fasilitator pelaksanaan Lelang, landasan aturan hukum yang dipakai adalah Pasal 14 Undang-Undang Nomor 4 Tahun 1996 Bakti.

${ }^{19}$ Fuady, M. (2007). Hukum Kontrak (Dari Sudut Pandang Hukum Bisnis), Bandung, PT. Citra Aditya 39

${ }^{20}$ Sembiring, J. J., \& SH, M. (2011). Cara Menyelesaikan Sengketa di Luar Pengadilan. Visimedia. hal,

21 Poerwoto, H. (2001). Hak Tanggungan Sebagai Lembaga Jaminan Atas Tanah. Vidya, 9(2). 
Tentang Hak Tanggungan yang mengisyaratkan bahwa Pelaksanaan Lelang Hak Tanggungan memiliki kekuatan eksekutorial yang sama dengan putusan hukum pengadilan yang telah berkekuatan hukum tetap (inkracht van gewijsde). Tetapi perlu penulis sampaikan apabila objek lelang Jaminan Hak Tanggungan terdapat perlawanan hukum dari Debitur ataupun pihak lain, maka Balai Lelang Swasta ataupun KPKNL tidak memiliki kewenangan untuk melakukan eksekusi pengosongan atas objek lelang yang sudah dibeli oleh peserta/pembeli lelang. Bahwa kewenangan pelaksanaan Eksekusi Pengosongan terhadap suatu objek merupakan kewenangan badan peradilan. ${ }^{22}$ Sedangkan didalam prakteknya Pengadilan tidak dapat langsung melaksanakan Eksekusi Pengosongan terhadap objek Lelang bermasalah yang dilelang oleh Balai Lelang Swasta. ${ }^{23}$

Hal tersebut terjadi karena Pengadilan menganggap bahwa terhadap Objek Lelang yang dijual oleh Balai Lelang Swasta tidak terdapat peletakkan sita (beslag) oleh badan Pengadilan. Sementara prosedur hukum untuk melakukan eksekusi pengosongan mewajibkan harus adanya penetapan sita terlebih dahulu oleh Pengadilan, kemudian dengan dasar itu dapat dilakukan eksekusi pengosongan (H.I.R / R.B.G). ${ }^{24}$

1. Hambatan Penyelesaian Kredit Macet melalui Fiat Eksekusi di Pengadilan

a) Hambatan Yuridis

Pada hakekatnya penanganan perkara kredit macet melalui pengadilan melalui proses yang tidak sederhana, dalam penanganan permohonan fiat eksekusi atas perkara kredit macet melalui pengadilan negeri ada beberapa tahapan yang harus dijalani. Setiap akan berganti tahap, harus didahului dengan dikeluarkannya Penetapan oleh Ketua Pengadilan Negeri, dari penetapan tersebut kemudian dilanjutkan dengan petunjuk dari Panitera Sekretaris Pengadilan Negeri Sengkang kepada pegawai/staf pengadilan untuk melakukan tugasnya. Dengan kata lain penanganan perkara kredit macet melalui badan peradilan

22 Usman, R. (1999). Pasal-pasal tentang hak tanggungan atas tanah. Penerbit Djambatan.

${ }^{23}$ Muljono, E. L., Tunggal, H. S., \& Tunggal, A. W. (1996). Eksekusi grosse akta hipotek oleh bank. Rineka Cipta.

${ }^{24}$ wawancara Burhanuddin, Ketua Pengadilan Negeri Sengkang 15 Agustus 2019 
melalui badan peradilan melalui proses yang berbelit-belit dan tidak sederhana. ${ }^{25}$

Sebagaimana diketahui bahwa prosedur penanganan permohonan Fiat Eksekusi melalui badan peradilan kurang ideal dan harus menempuh waktu yang cukup lama, padahal perhitungan kerugian bank (bunga) berjalan terus dan tidak dapat ditangguhkan sehingga pada umumnya proses penanganan Fiat Eksekusi atas kasus kredit macet tidak dapat ditempuh dalam waktu yang cepat, hal ini dapat dilihat sejak diberlakukannya Undang-Undang Hak Tanggungan terdapat banyak perkara tentang permohonan Fiat Eksekusi Untuk menyelesaikan kasus kredit macet yang diajukan kepada Pengadilan Negeri memakan waktu cukup lama yaitu rata-rata memakan waktu hingga 2 tahun bahkan ada juga yang sudah berjalan lebih dari 4 tahun tapi belum dapat dituntaskan, artinya proses penyelesaian perkara kredit macet di Pengadilan berjalan lama. Demikian juga halnya dalam dunia praktek, biaya tidak resmi sering dijumpai di lingkungan pengadilan, biaya tersebut dikenakan oleh pihak tertentu selaku penjual jasa hukum. ${ }^{26}$

Sebagai contoh, biaya pengambilan berkas di Pengadilan, pengalaman menunjukkan bahwa berkas tersebut tidak akan dikerjakan atau diserahkan bila pemohon hanya membayar biayaresmi saja, jadi harus membayar pula biaya tidak resmi. Sebagaimana diketahui dalam kasus kredit macet yang banyak ditangani hambatan yuridis yang banyak ditemui dalam praktek, adalan rawan sekali muncul upaya hukum perlawanan pihak ketiga (derden verzet) atau perlawanan dari pihak debitur yang tidak puas obyeknya akan dieksekusi. 27

b) Hambatan Non Yuridis

Selain hambatan yuridis yang banyak timbul dalam proses penanganan fiat eksekusi, hak tanggungan di Pengadilan Negeri, maka dari hasil penelitian yang dilakukan di lokasi maupun dan hasil wawancara

25 wawancara Burhanuddin, Ketua Pengadilan Negeri Sengkang 15 Agustus 2019

${ }^{26}$ wawancara staf Bank Rakyat Indonesia, Bagian kredit. 22 Agustus 2019.

${ }^{27}$ Ali, A. (1995). Liku-liku sejarah perbankan Indonesia. Grasindo. 
dengan para narasumber maka hambatan non yundis dapat menyebabkan hambatan dalam proses penanganan fiat eksekusi. Umumnya para penegak hukum di Pengadilan masih kurang dedikasinya maupun pengabdiannnya pada masyarakat, ${ }^{28}$ dalam arti penegak hukum tersebut punya orientasi pribadi apabila ada orang yang berpengara di pengadilan dapat memenuhi semua keinginan si penegak hukum maka segala urusannya di Pengadilan akan diperlancar, tapi kalau tidak dapat mengerti kemauan penegak hukumnya maka urusannya di Pengadilan bisa menjadi berbelit-belit, hal ini benar-benar nyata terjadi, karena disisi lain masih ada penegak hukum advokat, apabila prinsipal yang bersangkutan memberikan kuasa kepada seorang Advokat untuk mengurusi perkaranya maka kepiawaian dan kemahiran advokat dalam beracara di pengadilan sangat menentukan kelancaran suatu perkara. ${ }^{29}$

Faktor niat dan itikad Advokat yang memang ingin membantu atau bahkan tidak jarang pula Advokat yang sengaja mengulur-ulur waktu dengan berbagai macam trik yang bertujuan menghambat suatu perkara demi kepuasan kliennya. ${ }^{30}$ Berdasarkan fakta dan penelitian di lapangan sebagian besar Pengadilan Negeri di Indonesia menunjukkan bahwa ruang pengadilan yang dapat digunakan beracara masih kurang, sehingga ketika akan mengadakan lelang terhadap obyek jaminan kredit macet, maka tidak jarang para pihak terkait masih harus menunggu ruang sidang yang bisa digunakan, sekalipun ada ruang sidang yang kosong tetapi ukurannya kurang memadai dan tidak bisa menampung jumlah peserta lelang atau penonton yang jumlahnya tidak bisa dibilang sedikit. Pihak yang terkait dengan pelelangan harus an tre dan rela mengalah dengan sidang-sidang yang lain, terutama sidang

\footnotetext{
${ }^{28}$ A. Ali (2002). Keterpurukan hukum di Indonesia: penyebab dan solusinya. Ghalia Indonesia. 118

${ }^{29}$ Abdul Rasyid Priyatno, (2002), Arbitrase Dan Alternatif Penyelesaian Sengketa, Jakarta, Bani. hal 132

30 Wiwie Heryani, A. A. (2012). Menjelajahi Kajian Empiris terhadap Hukum. Kencana Prenada Media. Jakarta
} 
perkara pidana yang jumlahnya sehari bisa belasan perkara, ditambah lagi dengan kurang efektifnya pengaturan jadwal sidang.

2. Upaya Mengatasi Hambatan dalam Penyelesaian Kasus Kredit Macet di Pengadilan.

a) Mengatasi Hambatan Yuridis

Proses anmaning dari Pengadilan Negeri adalah tindakan teguran yang dilakukan oleh Ketua Pengadilan Negeri kepada debitur atau termohon eksekusi agar segera menyelesaikan kewajibannya kepada kreditur atau pemohon eksekusi, yaitu membayar kredit. ${ }^{31}$ Bukankah pihak kreditur atau bank sendiri sudah melakukan teguran kepada debitur yang pembayaran kreditnya mulai macet, demikian pula pihak advokat tentunya telah melakukan teguran kepada si debitur tersebut.

Adanya upaya hukum perlawanan (verzet), maupun perlawanan dari pihak ketiga (derdenverzet) dapat menyebabkan penanganan perkara kredit macet di Pengadilan Negeri menjadi berlarut-larut, tidak bisa segera diselesaikan. Tidak ada cara lain yang dapat dilakukan oleh pemohon fiat eksekusi apabila ternyata setelah dilaksanakan sita jaminan tiba-tiba muncul upaya hukum perlawanan tersebut kecuali harus dihadapi dimuka persidangan. Upaya hukum perlawanan adalah upaya hukum luar biasa oleh karenanya tidak bisa menangguhkan eksekusi, sebagaimana ketentuan pasal 207 ayat (3) HIR. Pihak pemohon fiat eksekusi tidak boleh tinggal diam, dan tetap saja harus berusaha di persidangan dengan mengajukan bukti-bukti maupun saksi-saksi yang dapat mendukung permohonan fiat eksekusinya. Upaya hukum verzet maupun derdenverzet tidak boleh dihindari, apabila dihindari justru meyebabkan permohonan fiat eksekusi yang diajukan oleh kredit atau pemohon eksekusi dihentikan dan dibatalkan oleh pengadilan, akibatnya kredit yang sudah macet tidak dapat diselesaikan Pengadilan akan menagguhkan proses fiat eksekusi apabila perlawanan tersebut nampak benar-benar beralasan.

\footnotetext{
${ }^{31}$ Ali Hasyim, (1995), Manajemen Bank, Jakarta, Bumi Aksara
} 
b) Mengatasi Hambatan Non-Yuridis dari Faktor Penegak Hukum Faktor penegak hukum sangat berpengaruh sekali dalam proses penanganan suatu perkara, terutama yang berkaitan dengan masalah yang sedang diteliti. Tidak jarang penanganan suatu perkara menjadi berlarut-larut, apalagi penanganan permohonan Fiat eksekusi, hal ini disebabkan adanya penegak hukum yang mempunyai motivasi pribadi dan kurang berdedikasi pada pekerjaannya. ${ }^{32}$ Upaya yang dapat ditempuh untuk mengatasi hambatan yang muncul dari faktor penegak hukum ini adalah dengan meminta petunjuk dari atasannya atau kepada komisi hukum nasional yang ada, misalnya kepada Pengadilan Tinggi. Mahkamah Agung Republik Indonesia. Komisi Yudisial atau Komisi Ombudsman Nasional. Petunjuk maupun kebijakan yang berasal dari atasan atau komisi tersebut diharapkan dapat mengubah perilaku dan pola pikir penegak hukum yang ada di bawah pengawasannya, sehingga penanganan suatu perkara tidak berlarutlarut. 33

c) Mengatasi Hambatan Non-Yuridis dari Faktor Sarana dan Prasarana Mengatasi hambatan dari faktor sarana/fasifitas ini, dikemudian hari maka disetiap Pengadilan Negeri harus mengajukan anggaran kepada pemerintah untuk menambah jumlah ruang sidang di lingkungan Pengadilan. Penambahan ruang sidang yang memadai diharapkan tidak terjadi lagi pelaksanaan lelang yang harus menunggu sampai selesainya sidang perkara yang lain. Namun penambahan jumlah ruang sidang tersebut harus diimbangi dengan peningkatan etos kerja dan disiplin waktu oleh penegak hukum, kalau ruang sudah ditambah tapi perilaku tidak berubah akhirnya tetap sama saja. Selain itu, seharusnya di tiap wilayah hukum suatu Pengadilan Negeri setidaknya terdapat satu Kantor Lelang yang bertugas, jadi antara Pengadilan Negeri dan Kantor

32 wawancara Hakim Pengadilan Negeri Sengkang, Henroh, 20 Agustus 2019.

33 Budi Harsono, (2006), Konsepsi Pemikiran Tentang Undang-Undang Hak Tanggungan Hasil Seminar, Bandung, 41 
Lelang Negara tidak perlu menempuh jarak terlalu jauh atau memakan waktu yang lama untuk berkoordinasi soal pelaksanaan Lelang.

d) Mengatasi Hambatan Non-Yuridis dari Faktor Masyarakat dan Budaya Penyebab terjadinya kredit macet selama ini banyak yang disebabkan oleh faktor kurang mengertinya masyarakat tentang kewajibannya dalam perjanjian kredit. Anggapan sebagian masyarakat bahwa yang penting terima uang, urusan hukum nanti saja masih tetap dipegang teguh, begitu pula adanya prinsip "pertemanan" antara pejabat bank dengan pihak debitur yang akan menerima kredit. Pengertian aturan hukum perkreditan harus benar-benar ditanamkan kepada colon debitur, begitu pula hak akan kewajiban debitur dalam menerima kredit. 34

Kepastian hukum, harus benar-benar ditegakkan oleh bank terhadap debitur yang macet. Penegakan hukum berasal dari masyarakat dan bertujuan untuk mencapai kedamaian dalam masyarakat, oleh karena itu masyarakat dapat mempengaruhi penegakan hukum tersebut, sementara ini masyarakat masih memandang sebelah mata mengenai pentingnya kesadaran hukum akan sistem hukum yang berlaku di Indonesia. ${ }^{35}$ Pemahaman dan sosialisasi hukum yang benar kepada masyarakat tentang kepastian hukum merupakan yang sangat penting untuk dilakukan, terutama memberikan pemahaman tentang hak dan kewajiban apabila terkait dalam suatu perjanjian. Pihak Bank telah berkali-kali memberikan pengertian kepada calon debitur sebelum menerima kredit, terutama mengenai kewajibannya dalam mengangsur atau membayar kreditnya, diharapkan dikemudian hari tidak sarnpai terjadi kasus kredit macet dalam pencairan kredit.

34 Budi Harsono, (2006), Konsepsi Pemikiran Tentang Undang-Undang Hak Tanggungan Hasil Seminar, Bandung, hal 68

35 Riyanto, B., \& Perusahaan, D. D. P. (2012). Edisi 4. BPFE, Yogyakarta. hal 93 


\section{KESIMPULAN DAN SARAN}

Pelaksanaan eksekusi objek Hak Tanggungan dalam penyelesaian dari pembiayaan bermasalah, bank selaku pemegang Hak Tanggungan atas objek jaminan dengan cara mengajukan permohonan Eksekusi Hak Tanggungan secara tertulis kepada Kepala Kantor Pelayanan Kekayaan Negara dan Lelang (KPKNL), baik dengan menggunakan jasa pra lelang Balai Lelang Swasta maupun secara langsung kepada KPKNL ters ebut sebagai yang bertugas untuk menyelenggarakan lelang. Kendala yang dialami pada awal pelaksanaan parate eksekusi hak tanggungan diantaranya adalah perlawanan yang dilakukan oleh debitur atas upaya eksekusi yang akan dilakukan oleh Bank. Tidak jarang ketika mengetahui bahwa bank akan melakukan upaya eksekusi atas tanah dan atau bangunan yang menjadi jaminan kredit, debitur yang beritikad tidak baik membuat perlawanan dengan mengajukan gugatan ke Pengadilan Negeri. Adanya hubungan kekerabatan di suatu daerah yang sangat menyulitkan untuk menjual objek jaminan yang dilelang, karena merasa debitur adalah keluarga dari mereka dan adanya rasa persaudaraan yang sangat tinggi diwilayah Bugis khususnya kabupaten Wajo, sehingga pembeli angunan tersebut tidak ada.

Disarankan pemegang Hak Tanggungan, merupakan pegangan dan dasar hukum berlakunya parate eksekusi sebagai sarana pada saat debitur cidera janji atau wanprestasi, dan pihak bank yang akan datang diharapkan untuk berhati - hati dalam proses menyalurkan kredit kepada masyarakat, dengan memperhatikan, sebagai prinsip kehatian-hatian dalam pemberian kredit, dan bagi pemegang Hak Tanggungan, jika melakukan pelelangan ke KPKNL diharapkan untuk dapat berhatihati, karna besarnya masalah yang akan dihadapi bagi para pihak, baik berupa adanya perlawanan dari debitur maupun sulitnya mencari pembeli lelang, hal ini disebabkan karna adanya objek yang akan di lelang mengalami masalah di lapangan, baik dari segi pengosongan maupun adanya gugatan dari pihak yang merasa dirugikan.

\section{REFERENSI}

A. Ali (2002). Keterpurukan hukum di Indonesia: penyebab dan solusinya. Ghalia Indonesia.

Ali, A. (1995). Liku-liku sejarah perbankan Indonesia. Grasindo. 
Ali Hasyim, (1995), Manajemen Bank, Jakarta, Bumi Aksara

Abdul Rasyid Priyatno, (2002), Arbitrase Dan Alternatif Penyelesaian Sengketa, Jakarta, Bani.

Usman, R. (1999). Pasal-pasal tentang hak tanggungan atas tanah. Penerbit Djambatan.

Budi Harsono, (2006), Konsepsi Pemikiran Tentang Undang-Undang Hak Tanggungan Hasil Seminar, Bandung

Riyanto, B., \& Perusahaan, D. D. P. (2012). Edisi 4. BPFE, Yogyakarta.

Pratama, B. A. (2010). Analisis faktor-faktor yang mempengaruhi kebijakan penyaluran kredit perbankan (Studi pada Bank Umum di Indonesia Periode Tahun 20052009) (Doctoral dissertation, Universitas Diponegoro).

Emerson, J. (2001). Alternatif Penyelesaian Sengketa di luar Pengadilan (negosiasi, mediasi, konsiliasi dan arbitrasi). Jakarta: Gramedia Pustaka.

(2001), Alternatif PenyelesaianSengketa Di Luar Pengadilan, Jakarta, Gramedia Pustaka Utama

Muljono, E. L., Tunggal, H. S., \& Tunggal, A. W. (1996). Eksekusi grosse akta hipotek oleh bank. Rineka Cipta.

Poerwoto, H. (2001). Hak Tanggungan Sebagai Lembaga Jaminan Atas Tanah. Vidya, 9(2).

Hadimulyo, M. A. (1997). Kajian Alternatif Penyelesaian Sengketa di Luar Pengadilan. ELSAM, Yakarta.

Rahman, H. (1998). Aspek-Aspek Hukum Pemberian Kredit Perbankan di Indonesia, citra Aditya Bakti.

Satrio, J. (1998). Hukum jaminan, hak jaminan kebendaan, hak tanggungan. Citra Aditya Bakti.

Syarif, F. (2019). Perkembangan Hukum Ekonomi Syariah di Indonesia. Pleno Jure, 9(2), $1-16$. 
Munir Fuady, (2006), Hukum Perkreditan Kontemporer, Bandung, Citra Aditya Bakti

Fuady, M. (2007). Hukum Kontrak (Dari Sudut Pandang Hukum Bisnis), Bandung, PT. Citra Aditya Bakti.

Zainul Arifin, M. B. A. (2012). Dasar-dasar manajemen bank syariah. Pustaka Alvabet.

RETNO, R. D. H. (2013). Pelaksanaan Pembiayaan Murabahah Emas Di Bank Danamon Syariah Sidoarjo (Doctoral dissertation, Faculty of Law).

Sembiring, J. J., \& SH, M. (2011). Cara Menyelesaikan Sengketa di Luar Pengadilan. Visimedia.

Sudikno, M. (2005). Mengenal Hukum Suatu Pengantar. Yogyakarta: Liberti.

Suyatno, T. (1988). Kelembagaan perbankan. Gramedia Pustaka Utama. a

Wijoyo Suprapto, 2007, Mekainisme Alternatif Penyelesaian Sengketa, Jakarta, Anaska

Sutarno. (2004). Aspek-aspek hukum perkreditan pada bank. Alfabeta.

Untung, H. B. (2000). Kredit perbankan di Indonesia. Andi.

Sutan Remy Sjahdeini, S. H. (2018). Perbankan Syariah: Produk-produk dan aspek-aspek hukumnya. Kencana.

Situmorang, V. M., \& Sitanggang, C. (1993). Grosse Akta dalam pembuktian dan Eksekusi. Rineka Cipta.

Wiwie Heryani, A. A. (2012). Menjelajahi Kajian Empiris terhadap Hukum. Kencana Prenada Media. Jakarta 